\title{
After Work: Anticipatory Knowledge on Post-Scarcity Futures in John Barnes's Thousand Cultures Tetralogy
}

\author{
By Michael Godhe
}

\begin{abstract}
What would happen if we could create societies with an abundance of goods and services created by cutting-edge technology, making manual wage labour unnecessary - what has been labelled societies with a post-scarcity economy. What are the pros and cons of such a future? Several science fiction novels and films have discussed these questions in recent decades, and have examined them in the socio-political, cultural, economic, scientific and environmental contexts of globalization, migration, nationalism, automation, robotization, the development of nanotechnology, genetic engineering, artificial intelligence and global warming.

In the first section of this article, I introduce methodological approaches and theoretical perspectives connected to Critical Future Studies and science fiction as anticipatory knowledge. In the second and third section, I introduce the question of the value of work by discussing some examples from speculative fiction. In section four to seven, I analyze the Thousand Culture tetralogy (1992-2006), written by science fiction author John Barnes. The Thousand Cultures tetralogy is set in the $29^{\text {th }}$ century, in a post-scarcity world. It highlights the question of work and leisure, and the values of each, and discusses these through the various societies depicted in the novels. What are the possible risks with societies where work is voluntary?
\end{abstract}

Keywords: post-scarcity, work, utopia, dystopia, critical future studies

Godhe, Michael: “After Work: Anticipatory Knowledge on Post-Scarcity Futures in John Barnes's Thousand Cultures tetralogy", Culture Unbound, Volume 10, issue 2, 2018: 246-262. Published by Linköping University Electronic Press:

http://www.cultureunbound.ep.liu.se 
What is perplexing is less the acceptance of the present reality that one must work to live than the willingness to live for work.

Kathi Weeks (2011: 2)

\section{Introduction}

The computerization of society, including automation and robotization, have been fiercely debated for many years (cf. Bodén's contribution in this issue). Current debate is coloured by recent developments in cybernetics, artificial intelligence, and communication media (cf. Frey \& Osborne 2013; Schwab 2016), but is also situated in the socio-political, cultural, economic, scientific and environmental contexts of globalization, migration, nationalism, the development of nanotechnology, genetic engineering and global warming.

In his thought-provoking book Four Futures: Visions of the World After Capitalism, sociologist Peter Frase argues that "two specters are haunting Earth in the twenty-first century: the specters of ecological catastrophe and automation" (Frase 2016: 1). Frase believes that we are facing a "contradictory dual crisis", of which the two elements are a scarcity of inhabitable places to live on Earth (as a consequence of climate change) and an abundance of unemployed workers (as a consequence of automation and robotization) (Frase 2016: 1-3). ${ }^{1}$

A further pathology concerns the challenge of balancing time in late modern societies. According to sociologist Jiri Zuzanek, after the financial crisis of 2008 we have seen "a polarisation of time use along employment lines, with parts of the employed population experiencing time pressure [...], while others are confronted with enforced rather than chosen leisure" (Zuzanek 2017: 312). Therefore, the question of how we should organize a sustainable society and how we should (re) distribute wealth is urgent.

Recently, scholars and public intellectuals such as Paul Mason (2016), Rutger Bregman (2016), and Roland Paulsen (2017) have returned to the idea of a universal basic income (although emphasizing the pros and cons depending on the form in which it is implemented), since capitalism as we know it is coming to an end (post-capitalism). Why, when we have all the technological means needed to decrease the amount of labour we carry out, are we continuing along the same trajectory? One of the reasons according to Paulsen, and of interest for this essay, is that we are still burdened by a work ethos that is incompatible with the time we live in (Paulsen 2017). Work is not only "defended on grounds of economic necessity and social duty; it is widely understood as an individual moral practice and collective ethical obligation", as sociologist Kathi Weeks states. Work is considered to be what defines us in terms of self-fulfilment, social recognition and status; and further it is seen as fundamental for a stable society (Weeks 2011: 11, cf. Paulsen 
2017: 33-123).

Weeks claims that questioning traditional work values is not to suggest that work is without value, but "that there are other ways to organize and distribute that activity and to remind us that is also possible to be creative outside the boundaries of work" (Weeks 2011: 12). One influential arena for imagining and discussing other ways for organizing and distributing labour is speculative fiction: ${ }^{2}$ in the utopian and dystopian genres creative reorganization of work and leisure are an essential part of the narrative, but few works have gone as far as to abolish labour until the last decades. I suggest that speculative fiction (especially science fiction) in recent decades have in some sense undergone a transition from being work-oriented to imagining societies where work is voluntary - for better or worse. They are exploring possible futures where societies with an abundance of goods and services are created by cutting-edge technology, making manual wage labour unnecessary - what has been labelled societies with a post-scarcity economy (cf. Aguilar-Millan et al 2010, Barbour 2012).

One such example is the Thousand Cultures tetralogy (1992-2006) by John Barnes (b. 1957), where the idea of societies with post-scarcity economy are explored in relation to uncertainties that arise in the post-cold war period. In this article, I analyse how Barnes depicts the pros and cons of such a future: Is work still connected to self-fulfilment and social recognition? What are the possible risks with societies where work is voluntary? Situated in the social, political and economic contexts of globalization, posthumanism and transhumanism, and the war on terror, as well as environmental issues, the Thousand Cultures tetralogy discusses the possible nature of work and leisure in societies with post-scarcity economy. It depicts our galaxy in the $29^{\text {th }}$ century through the eyes of the protagonist Giraut Leones, a troubadour brought up in a medieval culture, celebrating courtly codes of honour. Since goods are abundant in the Thousand Cultures, it is a world of post-scarcity economies. A universal basic income has been implemented in one form or another with few exceptions, but far from all societies are post-labour.

At the beginning of the first novel, the springer has just been implemented. This is a technological innovation that makes instantaneous travel between the planets in the galaxy possible. With the arrival of the springer, people, goods, ideas and culture are beginning to flow between the different parts of the galaxy after centuries of isolation, and in this sense the novels deal with and interpret contemporary questions of globalization and recent developments in identity politics (cf. Godhe 2018) coupled to the question of work in post-scarcity societies. I give a thumbnail sketch of the plot in the tetralogy below.

In the first section of this article, I introduce methodological approaches and theoretical perspectives connected to critical future studies (Goode \& Godhe 2017) and how the science-fiction genre works as anticipatory knowledge on pos- 
sible futures. In the second and third section, I introduce the question of the value of work by discussing some examples from speculative fiction, showing how the conception of work has transformed labour: no longer a necessary part of future imaginaries, it is re-imagined as a voluntary exercise. In section four to seven, I analyze the Thousand Culture tetralogy (1992-2006).

\section{Methodological and theoretical approaches to Critical Future Studies}

In our programmatic article "Beyond Capitalist Realism - Why We Need Critical Future Studies", Luke Goode and I stated that "CFS investigates the scope and constraints within public culture for imagining and debating different potential futures". The aim of CFS is "to contribute constructively to vigorous and imaginative public debate about the future-a futural public sphere-and to challenge a prevalent contemporary cynicism about our capacity to imagine alternative futures while trapped in a parlous present." (Goode \& Godhe 2017: 109). A capitalist realism "persuading citizens that there is no alternative to the onward march of globalized markets, finance capitalism, deregulation and environmental degradation" limits our scope for imagining alternatives to the present trajectory (Goode \& Godhe 2017: 110. See also Fisher 2009, Levitas 2013, Vint 2016, Paulsen 2017). Speculative fiction like the science-fiction-genre can be seen as a futural public sphere, "an important 'place' or 'room' for discussing the societal and cultural impact of science and technology" (Godhe 2018, cf. Bergström et al 2000). The science-fiction genre is a place focussing on extrapolating "human problems brought about by technological change" (Clarke 2010: 51, cf. Suvin 1979), anticipating alternative futures.

In our 2017 article, we also proposed a methodology for Critical Future Studies (Goode \& Godhe 2017: 109, 121-123) based on several questions, such as: What kind of future is evoked? Who would want to live in such a future (and who wouldn't)? These questions are helpful for investigating the pros and cons of the organization of work and leisure time in a post-scarcity economy, in terms of self-fulfilment and social recognition as well as possible risks with post-labour societies, with the example of Barnes's Thousand Cultures tetralogy.

The narrative in Thousand Cultures tetralogy is neither dystopic nor utopic, a characteristic it shares with many late-modern works in speculative fiction (Godhe 2010). It contains dystopian elements juxtaposed to utopian elements and brings to the fore questions on latent but undesirable consequences of post-scarcity that may arise if we continue along the present trajectory. Depending partly on "subjective disposition and taste for different futures" it is "often possible to discern both utopian and dystopian imagery within a single text. [...] But it is 
often bound up with structural inequalities of class, gender, race, culture and geography. Who stands to gain and who stands to lose are always critical and unavoidable questions" (Goode and Godhe 2017: 121).

Examining the nature of dystopias Frédéric Claisse and Pierre Delvenne (2015) argue that a successful dystopia "aims at making itself obsolete: once the world it depicts is identified as a possible future, it seems to empower its readers again, restoring a 'sense of possibilities' that eventually makes alternative pathways thinkable" (Claisse \& Delvenne 2015: 155-156). Dystopias, in this sense, are anticipatory knowledge of possible futures based on extrapolation of current societal, economical, technological and scientific tendencies. I claim that science-fiction works containing both utopian and dystopian elements, like Barnes's tetralogy, can be used as anticipatory knowledge. The Thousand Cultures tetralogy makes it possible to open up the scope for alternative futures and hopefully endowing the reader "with the capacity to conceive the future and act in accordance with these representations" (Claisse and Delvenne 2015: 157).

\section{The value of work}

The question of the value of labour and the relationship between work and leisure were discussed as early as the works of the classical Greek philosophers, and later in the utopian tradition that started with Francis Bacon and Thomas More (cf. Manuel and Manuel 1979, Claeys 2011, Zuzanek 2017). Work took on new meaning with the utopian socialists in the $19^{\text {th }}$ century, who saw their utopias as sustainable solutions to the pathologies of industrialization - rapid urbanization, the destruction of the environment, the exhausting of the labour force, the use of child labour, et cetera (cf. Hobsbawm 1975, Manuel \& Manuel 1979).

Reducing the number of working hours and abolishing child labour as well as discussing the quality of work were among the questions raised by utopian socialists in the $18^{\text {th }}$ and $19^{\text {th }}$ centuries. In this sense, the conception of work and leisure deviated from the classical economists of the $18^{\text {th }}$ century, who believed that there "was an acceptance that those who worked (i.e. wage-labourers) would seek to avoid work and to indulge in leisure, and it was recognised that incentives as well as sanctions would be needed to encourage the workforce to work hard" (Spencer 2009: 97). While almost every utopian socialist considered organized manual labour to be a necessary and constitutive part of their utopian societies, British writer and intellectual William Morris (1834-1896) was an exception since work in his utopia should be voluntary. In a review of Edward Bellamy's (1850-1898) now classic utopian novel Looking Backward: 2000-1887, Morris found Bellamy's ideas of life contestable: "a machine-life is the best which Mr Bellamy can imagine for us on all sides; it is not to be wondered at then that his only idea of making 
labour tolerable is to decrease the amount of it by means of fresh and ever fresh machinery." (Morris 1889: 357)

Morris rejected the claim of almost every other utopian writer, that factory work (although limited) is an essential part of modern life even in a post-scarcity economy. He was, in that sense, certainly not typical of socialist or utopian writers in his times. Morris imagined a future in which the absolute minimum number of machines produced more than just the bare necessities, while the citizens could choose whether they wanted to work or not. Those who chose to work became engaged in activities connected to art, which, in Morris's view, was the same as handicraft or skilled labour (Morris 1890).

Like in many other utopian stories from the $19^{\text {th }}$ century, the inhabitants in Morris's utopia live longer and healthier lives, and they are more beautiful and prosperous (Morris 1890). But Morris's legacy is first and foremost the question of the value of work, and the relation between work and leisure. Morris was influenced by the French utopian writer Charles Fourier (1772-1837) and his concept of "attractive work" (Spencer 2009: 98). As sociologist John Stirling points out (2002: 130), for Morris "the central element of his conception of work was joy in labour". Nevertheless, few works in the science fiction genre abolished labour until the post-war period. The belief in progress, in combination with the bourgeois work ethos, still holds its grip on the imagination and on ideas of organized leisure (cf. Zuzanek 2017).

Indeed, the idea of the universal basic income, proposed in many $19^{\text {th }}$ century utopias (although often linked to the re-organization of labour and to citizenship), was for a long time stigmatized in the $20^{\text {th }}$ century when the pendulum swung from utopian visions in general (not just utopian socialism) to dystopian fictional accounts of society (Manuel and Manuel 1979, Godhe 2010, Claeys 2011). In dystopian novels such as Brave New World (1932) by Aldous Huxley and 1984 (1949) by George Orwell, both capitalism and socialism were criticized, and the continual rationalization of society and the belief in progress were contested, among other things. Today, dystopian imagery is commonplace in popular culture. Films such as Elysium (2013, dir. Neill Blomkamp) warn us for a future in which the privileged $1 \%$ has abandoned Earth to live in abundance in satellites or in planetary colonies, while the remaining population live in dire circumstances on a wasted and polluted Earth. In this paper, however, I will not focus on dystopian narratives of mass unemployment, social and economic inequality or other possible pathologies of an automatized and robotized world. 


\section{The end of work? The end of history? The end of culture? To boldly go...}

In the short story "The Good Work" from 1959, Theodor L. Thomas (1920-2005) describes a utopian world in which machines have replaced manual labour. Not everyone is happy with that, so the Ministry of Government Employment provides those who are unhappy with a job. The protagonist in the story takes a job as member of the maintenance crew of the building where he lives. It "consists of tightening the nuts on the expansion joints in the framework of the building". At the end of the story, we learn that another crew, the nightshift, loosens the nuts (Thomas 1959: 35). The story illustrates the fear that too much leisure will make us idle or discontent with life.

Many science fiction texts, films and television series in the $20^{\text {th }}$ and $21^{\text {th }}$ centuries have depicted possible worlds in which science and technology have radically changed the living conditions for humans, for better or for worse. The present article is not the place for a thorough discussion of the predecessors of Barnes's Thousand Culture tetralogy, but some works that change the status of work from an end in itself to a voluntary exercise are worth mentioning - such as the Star Trek franchise and the Culture series by Iain M. Banks.

The most famous example, and one of the few that depict the organization of work and leisure in a post-scarcity utopian future is Star Trek. The original series (1966-1969) depicts in many ways a post-labour world in a post-scarcity utopia, as does the second-run incarnation Star Trek: The Next Generation (1987-1994), and some of the other incarnations of the Star Trek fictional universe. As Peter Frase emphasizes, "the economy and society of that show is based on two basic technical elements": the "replicator", which produces and materializes objects for free (since there are no laws protecting intellectual and material property), and free energy to run the replicator "as well as anything else on the show" (Frase 2016: 48). The end of work and scarcity is the beginning of a new history in Star Trek - the exploration of the universe and encounters with alien races and other civilizations.

In his thought-provoking book on fun as a key element in entertainment (which he sees as a vital part of ordinary life), sociologist Alan McKee discusses, among other things, the post-scarcity utopian future in the Culture series (19872012) by Iain M. Banks (1954-2013). McKee connects the modern work ethos (in its various incarnations) and its origins to the development of a middle class in the 19th century, "that emphasise duty". This contrasts with both aristocratic and working-class philosophies (McKee 2016: 84). But what if we just for a moment imagine a world without duty - and with a post-scarcity economy where no one is being exploited? 
If there is no duty and no suffering, are we, as human beings, somehow lessened? If everything that anyone does in their lives is done for fun because they want to do it - do we lose something, something that we might call 'meaning' or 'purpose'? (McKee 2016: 87).

The Culture series by Ian M. Banks asks how much fun we can and should have, according to McKee. Banks does not depict a perfect universe in his novels. Devastating wars are being conducted in the galaxy, to mention one example. But in the culture of the Culture, the citizens are not indolent even if they "can get drunk/ stoned/tripped out or whatever just by thinking about it" and can "enhance sexual pleasure" by altering their reproductive organs (Banks cited in McKee 2016: 89). As in Morris's utopia, some people work to obtain pleasure and fun, or some kind of contentment. The Culture is "a form of social organisation where everybody is motivated by fun", but where fun is also connected to ethical questions. Killing someone for fun, for example, is not accepted in the Culture (McKee 2016: 91).

As in Banks's Culture, fun is a central theme in John Barnes's Thousand Cultures tetralogy, as is also duty. Barnes, however, uses the conception of post-scarcity to ask urgent questions concerning several phenomena in our post-Cold War times - globalization, identity politics, automation, robotization, transhumanism and artificial intelligence.

\section{Diversity and stagnation}

The Thousand Cultures tetralogy shows the hopes and fears of a world beyond scarcity and beyond the need for physical labour. ${ }^{3}$ The action takes place in the $29^{\text {th }}$ century. We follow the protagonist Giraut Leones, a young troubadour living in Nou Occitan on the planet Wilson, a society that celebrates values and lifestyles from the Earth's Middle Ages, namely the courtly culture known as Occitan.

In the Thousand Cultures galaxy, there are 26 inhabitable planets including Earth. The other 25 have been colonized from Earth and humanity now encompasses 1228 different societies with distinct and monolithic cultures, more or less with post-scarcity economy. Aintellects (artificial intelligences), with some exceptions, perform most of the necessary manual labour. Nanos (nanotechnology robots) are building or terraforming (that is, transforming to Earth-like conditions) the different environments on the 26 inhabitable planets in the galaxy. Since aintellects do all the work necessary to survive, Giraut doesn't have to worry about work, or anything but the code of honour of his courtly culture.

The 1228 different societies are politically and socially organized through certain distinctive cultures, may they be courtly, religious, military, or based on another identity characteristic. A galactic supranational organization, the Council 
of Humanity, ensures that the union of 1228 cultures on 26 planets is successful. This is necessary, because some of the cultures that have evolved over centuries of isolation have xenophobic tendencies and oppose cultural and economic impulses from outside societies. If necessary, the Council of Humanity will enforce unity. Another task of the council is to prepare humanity for an external threat, although this is kept secret from the general population to avoid panic, a potential invasion by a hostile alien race against which the Thousand Cultures must maintain a united front.

Without questioning, at least not in the beginning of the tetralogy, his Occitan heritage, Giraut spends his days with friends, drinking wine and courting beautiful young women who are members of the courtly culture. In short: trying to have fun. But with the implementation of the springer, all this is going to change. Members of a uniform interplanetary culture, emanating from Earth, so called Interstellars, are spreading in the universe, and Giraut and his friends are engaged in brutal fights with them. They detest Interstellars, "traitors to their own culture, imitators of the worst that came out from the Inner Worlds, bad copies of Earth throwing away all the wealth of their Occitan heritage" (Barnes 1992: 14).

The Thousand Cultures galaxy before the springer is characterized by both diversity and stagnation - diversity in the sense that the various cultures in the galaxy are distinctly unique, stagnation in the sense that no cultural exchange takes place until the springer arrives. The present state described in the first novel $A$ Million Open Doors is the result of a period of devastating world wars that ended in the $24^{\text {th }}$ century. Many minority cultures on Earth became almost extinct. So called culture founders were given permission to colonize the nearest planets in the solar system in order to transplant minority cultures. Since reliable historical sources were few, they could let myths "load in as real history" and reinvent tradition. It is often not obvious to those living in the different cultures what is based on historical sources and what is invented. After the colonization of the galaxy, humanity entered a period of cultural and scientific stagnation, since it was believed that the various cultures wanted to be isolated (Barnes 1992: 124, 188, Barnes 1998: 29-30).

As Peter Frase emphasizes, post-scarcity economy can have many faces. It may be organized around different egalitarian political systems, or it may result in extreme inequalities or even extinction of the poor (Frase 2016). And this is the case in Barnes's fictional universe. At the beginning of the tetralogy, the post-scarcity world that is depicted is a utopia where technology has made manual labour redundant. However, as the plot develops, many questions arise. Not every culture has abolished work and some capitalist monetary systems still exist (although Barnes is not very explicit with details here).

When discussing Cory Doctorow's science fiction novel Down and Out in the 
Magic Kingdom (2003), Frase emphasizes that Doctorow "grasps that within human societies, certain immaterial goods will always be inherently scarce: reputation, respect, esteem among one's peers" (Frase 2016: 60). And this is the case in Nou Occitan in A Million Open Doors. The cultures that are not organized around work have replaced labour with various lifestyles associated with a certain culture - in Giraut's case the courtly culture until he and his friends turn 25, when they are expected to develop some voluntary skill connected to Occitan culture. In this sense, work has not been abolished in Nou Occitan but labour after the youth period has become more of an avocation (as in William Morris's utopia).

In this post-scarcity society, immaterial values have replaced material values, wage-labour and social stratification. Preserving the ethos of courtly culture and protecting it from outside cultural influences are important for Giraut and his friends, and they detest the Interstellars' intergalactic culture and their impact on Occitan culture made possible by the springer.

Loyalty to your own culture has been mistaken for fun, and in the sequel, Earth Made of Glass (1998), Giraut states that most of the people in the Galaxy "lived in some version of a permanent summer camp". They were "doing some form of endless, fruitless self-development. The only real differences were whether they played at art, religion, science, or lifestyle. [...] Humanity as a whole was bored, and incapable of self-amusement" (Barnes 1998: 281-282). As an indication of unfulfillment, the suicide rate on Nou Occitan is high (Barnes 2001: 53). Life becomes deprived of meaning and cultural development in the isolated cultures stops. In "the post-economic world the only real problem is boredom" (Barnes 1998: 320). Human labour no longer has any worth because most tasks can be done better by machines. The exceptions are art and "interpersonal relations" (Barnes 2001: 198). The tetralogy also posits that culture becomes simulacra, a postmodern play mistaken for reality (cf. Baudrillard 1994[1981]):

To create a sense of meaning, and to resist the uniform interstellar culture whose spread the springer has made possible, different cultures attempt to preserve their uniqueness and 'purity' by refusing influences from outside (cf. Godhe 2018). In the post-scarcity galaxy depicted in the Thousand Cultures tetralogy, cultural identity has become the most important determinant of social category, connected to either performing unnecessary work or indulging in leisure activities.

\section{Hybridity and development: Breaking out of cultural identity}

The integration of 1228 cultures scattered on 26 planets in the galaxy is not without frictions and conflicts. In A Million Open Doors, Giraut travels to the planet Nansen. He becomes acquainted with the culture of the city Utilitopia in the state Caledony, a Christian capitalist culture permeated by a Lutheran work ethic. 
All citizens and "resident aliens" (including Giraut) must do manual labour four hours a day, even though it is possible for the aintellects and nanos to do almost all of the necessary work (Barnes 1992: 64). Work serves to discipline the citizens of Utilitopia: it makes them docile and ensures social stability. A surprised Giraut "had always assumed that everywhere else was something like Nou Occitan, solving the problem of the fully automatic economy by employing everyone at some interesting occupation. Obviously this place had other solutions" (Barnes 1992: 71).

Eventually, Giraut receives permission to establish a cultural center - if it does not contribute to "contamination of Caledon thought", as the authorities express it (Barnes 1992: 51-68, 84-87). The isolation from other planets and cultures has had societal and cultural consequences, but Utilitopia has recently implemented the springer, and things are going to change. In many ways, the work ethos from the 19th century has been taken to its extreme, and the consequences of laissez faire capitalism for societal and cultural development have become apparent. Everything in Utilitopia is valued by its potential to maximise utility and rationality - which can be seen as a refinement of Max Weber's thesis of the Protestant ethic and the spirit of capitalism (cf. Weeks 2011: 51-57). Cultural development in Utilitopia has ceased, since cultural expressions are not considered to be useful. Identity is connected to work - to utility and duty.

However, in his meetings with Utilitopians at his culture center, Giraut starts to see his own courtly culture and its rigid gender conventions in a new light (cf. Godhe 2018). The courtly culture is shallow, brutal, and one of the most extreme cultures in the galaxy "in enforcing gender differences" (Barnes 1992: 228). A form of ritual and symbolic rape occurs in the courtly culture, but even "real, violent rape was common in the Nou Occitan" (Barnes 1992: 229).

The Utilitopians he encounters on Nansen begin in their turn to liberate themselves from their rigid cultural conventions and to create hybrids between their local culture and Giraut's neo-Occitan culture. With permission from the Caledonian authorities, his students initiate an artistic movement, Inessentialism, that celebrates the value of l'art pour l'art, and fun without duty. Eventually, however, Giraut's Center for Occitan Art comes under attack from traditionalists fearing that he is contaminating Caledon thought by influencing his students. Suddenly, boredom is not the only real problem - cultural change can be extremely dangerous in some circumstances. Civil war breaks out in Utilitopia, and several of Giraut's new friends are killed in the struggle. The armed forces of the Council of Humanity restore order. The old regime is overthrown and Utilitopia becomes more receptive to outside influences. Giraut and the utilitopian Margaret (with whom Giraut has engaged in a relationship) are enlisted as operational field agents for the Council of Humanity, under the cover of cultural ambassadors. 


\section{Post-Scarcity, work and disaster}

In the second novel, Earth Made of Glass (1998), Giraut and the utilitopian Margaret are on a mission for the Council of Humanity. They travel to the planet Briand, the scene of one of the most infected conflicts in the Thousand Cultures. The two implanted cultures on Briand, Maya and Tamil, detest each other, and violence between them is common. Both cultures strive to minimize outside influences and oppose the implementation of the springer, which conflicts with the Council of Humanity's ambition to unite humanity. On Briand, the work ethos is even more tightly connected to cultural identity and authenticity. In this case, the strong emphasis on cultural identity brings the two civilizations on Briand to a devastating civil war, which eventually destroys all life and makes the planet uninhabitable for many years.

The two cultures are based on agriculture and handicraft, but the leaders have kept the population ignorant of the reinvention of their history, mainly to preserve the 'essence' of their cultures. In the Maya culture, priests and leaders conceal new technologies that can prevent farmers from starving: "if they are to be real subsistence farmers, when the crops fail, they have to starve. You can't tell them that with foodmakers, nanos, and electric power you can make all the food they could possibly want" (Barnes 1998: 187).

Earth Made of Glass shows how cultural identity connected to work is the basis for identity politics, protecting the two cultures on Briand from external cultural influences (cf. Godhe 2018). This is identity politics of the kind we have witnessed in recent decades with the rise of nationalist movements in Europe and the US, attempting to protect their cultural identity by sealing their borders (cf. Bonikowski 2017). The dystopian impulse in the novels warns us of the consequences of identity politics. The fear of globalization (in this case represented by the springer) destroying old cultural patterns by replacing them with a uniform global culture, leads to the reinforcement of regional and local identities, what has been labelled glocalization or re-embedding (cf. Hylland Eriksen 2014) and finally to xenophobia (cf. Godhe 2018).

\section{Into the box}

In contrast with much other contemporary science fiction, the Thousand Cultures tetralogy does not discuss environmental issues particularly deeply in the first two novels. Most of the cultures scattered throughout the galaxy have been established on planets carefully terraformed by nanos, but there is no discussion of whether the natural environments on the planets have an intrinsic value or not, as is the case in Kim Stanley Robinson's Mars Trilogy (1993-1996) (cf. Pak 2016).

In the third and fourth novels in the tetralogy, The Merchants of Souls (2001) 
and The Armies of Memory (2006), Giraut continues with his work as an operational field agent for the Council of Humanity. His missions bring him to Earth and we learn that the planet was crowded and "awfully beat up" after the last world war. No more is said about environmental issues, however. Nonetheless, Earth is not a particularly good place. Almost all citizens on Earth are living in mega-cities in small concrete boxes, spending their lives "consuming direct-to-brain entertainment" (Barnes 2001: 43). The citizens are pacified by virtual reality, having completed a compulsory period of seven years' work before being permitted to go into the box (Barnes 2006: 102-103).

Half of the voters on Earth claim that "the right to consume is the fundamental human right" (Barnes 2001: 39). Most of them do not use the springer for vacations or visits to other planets or other cultures, since they have already seen everything in virtual reality. They have no reason to leave their box. In fact, some Earth citizens spend all their lives in virtual reality, and "nearly forget that they're in a simulation at all". A quarter of the adult population of Earth have become solipsists. They "believe that nothing outside their apartments was real, that everything was generated by the aintellects to keep them pacified" (Barnes 2001: $133,155)$.

While technology has made post-scarcity life possible, it has also made it possible for people on Earth to withdraw from public life and spend most of their time isolated in virtual reality, forgetting that they are in a simulation. This is an extreme illustration of Jean Baudrillard's theory of simulacra and simulations, in which he suggests that we mistake representations for reality (Baudrillard 1994[1981]). On the other hand, people living outside the box, outside Earth on the colonies, are bound to stories, history, myths and legends of their own cultures, which is also a kind of simulacrum. These control the social order and determine how the social beings act - a kind of virtual reality created by other means.

The dystopian impulse concern the fear of how different media representations have the power to shape our conception of reality, and how mass entertainment has become a substitute for the public sphere and pacified the citizens (cf. Habermas 1989[1962]). This is particularly acute in a post-scarcity world in which the amount of work that needs to be done is limited or zero. In this sense, Barnes's tetralogy seems somewhat conservative, while it is more progressively imaginative in other ways. The cultural encounters enabled by the springer are opening up a galaxy in which work in many cultures becomes less connected to cultural identity, and where the interface between leisure and work is becoming increasingly blurred. The fear of cultural mixing in some cases leads to wars, while in other cases cultural encounters lead to societal and cultural development. 


\section{Conclusion: Anticipatory knowledge and a sense of possibility}

The computerization of society, including automation and robotization, is certainly on the agenda again, provoking both hopes and fears (Schwab 2016, Bridle 2018). Some fear that we will face a future with mass unemployment (Brynjolfsson and McAfee 2014) while others argue that we must rethink the way in which we organize society around work and return to the idea of a universal basic income (Mason 2015/2016, Frase 2016, Paulsen 2017).

As Kathi Weeks states, questioning traditional work values (but not necessarily that there are some values with work) is to insist on other ways of organizing and distributing labour (Weeks 2011: 11-12). One such arena with creative ideas of how to reorganize work and leisure time is speculative fiction (utopian and dystopian literature as well as the science-fiction genre). The organization of work and leisure has been part of utopian thought since ancient times, but only in the last decades, with few exceptions, utopian societies with a post-scarcity economy have been connected to post-work in speculative fiction. Even if utopian writers in the $18^{\text {th }}$ and the $19^{\text {th }}$ centuries reduced the amount of necessary manual labour needed to be done, work was an essential part of utopian thought.

In this paper, I've discussed the possible strengths and weaknesses of post-scarcity futures where machines replaced manual labour through some examples in general, but John Barnes's Thousand Cultures tetralogy in particular. In Barnes's fictional universe both leisure and work are connected to cultural identity. In societies where work has been redundant, leisure (or an avocation) is connected to pursuing a distinct and monolithic form of local or regional culture based on few and unreliable historical sources (and culture founder's permission to invent history). In societies where work has prevailed, labour has also been connected to cultural identity, to a kind of work ethos similar to how labour in our times still is something that defines our social being.

The possible pathologies of work or post-work in a post-scarcity economy are exposed in the tetralogy. As anticipatory knowledge, the tetralogy suggest that cultural isolation prevent a real liberation from the work ethos and how it is connected to self-fulfilment and social recognition. The tetralogy also reflects a contemporary world in which nationalist movements, illiberalism and isolationism are juxtaposed with capitalist realism, narrowing our scope by suggesting that there is no alternative. When mixing and hybridization occur in cultural encounters, communication technology becomes a means to liberate humanity and restore cultural progress.

At its best, the tetralogy empowers the readers and restores a sense of possibility. The utopian elements we find in the tetralogy, the fragile hope for a reunited and restored humanity make the imaginary reconstitution of society a possibility (cf. Levitas 2013), a society where the possible pathologies after work are avoided and other ways of self-fulfilment are feasible. 


\section{Culture Unbound}

Journal of Current Cultural Research

Michael Godhe is Senior Lecturer at Culture, Society and Media Production (KSM) at the Department for Studies of Social Change and Culture, Campus Norrköping at Linköping University. He is currently finishing a book on the mediatization of the space project in Sweden 1900-1957. E-mail: michael.godhe@liu.se

\section{Acknowledgements}

I would like to thank Luke Goode, Magnus Rodell, the editors of Culture Unbound and the two anonymous reviewers for helpful and insightful comments on the article.

\section{Notes}

${ }^{1}$ Robotization and automation more generally are not the only causes of unemployment, but in this essay it is a starting point for a larger discussion of work in utopian and dystopian fiction, including the science-fiction genre.

${ }^{2}$ In this paper, I use 'speculative fiction' as an umbrella term for utopian and dystopian fiction as well as the science-fiction genre. The term can also include genres such as fantasy, horror, zombie fiction, et cetera.

${ }^{3}$ The history behind the vision of the future invoked in the Thousand Cultures tetralogy is also part of science fiction's megatext (cf. Määttä 2006), with many analogies and references to other works in the science fiction genre. It is, however, beyond the scope of this article to discuss the intertexts.

\section{References}

Aguilar-Millan, Stephen et al (2010): "The Post-Scarcity World of 2050-2075", The Futurist, 44:1, 34-40.

Barbour, Charles (2012): The Marx-Machine: Politics, Polemics, Ideology, Lanham, Md: Lexington Books.

Barnes, John (1992): A Million Open Doors, New York: Tor.

Barnes, John (1998): Earth Made of Glass, New York: Tor.

Barnes, John (2001): The Merchants of Souls, New York: Tor.

Barnes, John (2006): The Armies of Memory, New York: Tor.

Baudrillard, Jean (1994[1981]): Simulacra and Simulation, Ann Arbor: The University of Michigan Press.

Bergström, Martin et al (2000): 'Publika kulturer. Utgångspunkter för kulturhistoriska analyser av den medierade kommunikationens teknik och pedagogik", Martin Bergström et al (eds.): Publika kulturer: Att tilltala allmänheten, 1700-1900. En inledning, Uppsala: Institutionen för idé- och lärdomshistoria, 2000, 5-18.

Bonikowski, Bart (2017): "Ethno-Nationalist Populism and the Mobilization of Collective Resentment", The British Journal of Sociology, 68:1, 181-213.

Bregman, Rutger (2016): Utopia for Realists and How We Can Get There, London: Bloomsbury Publishing.

Bridle, James (2018): New Dark Age: Technology and the End of the Future, London: Verso.

Brynjolfsson, Erik and Andrew McAfee (2014): The Second Machine Age: Work, 


\section{Culture Unbound}

Journal of Current Cultural Research

Progress, and Prosperity in a Time of Brilliant Technologies, New York \& London: W.W. Norton \& Company.

Claisse, Frédéric \& Pierre Delvenne (2015): "Building on Anticipation: Dystopia as Empowerment", Current Sociology, 63:2, 155-169.

Clarke, Amy M. (2010): Ursula K. Le Guin's Journey to Post-Feminism, Jefferson, North Carolina \& London: McFarland \& Company, Ink., Publishers.

Claeys, Gregory (2011): Searching for Utopia: The History of an Idea, London: Thames \& Hudson.

Fisher, Mark (2009): Capitalist Realism: Is there no Alternative?, Winchester: Zero Books.

Frase, Peter (2016): Four Futures: Visions of the World After Capitalism, London: Verso.

Frey, Carl Benedikt \& Michael Osborne (2013): The Future of Employment, Oxford: Oxford University.

Godhe, Michael (2010): “'Literature of estrangement': Några linjer i feministisk utopi- och sf-forskning", Michael Godhe \& Jonas Ramsten (eds.): Möjliga världar: Tekniken, vetenskapen och science fiction, Stockholm: Carlssons, 157-178.

Godhe, Michael (2018): “'The Old Stories Had Become Our Prison' Globalisation and Identity Politics in John Barnes's Science Fiction Novels A Million Open Doors and Earth Made of Glass", Fafnir: Nordic Journal of Science Fiction and Fantasy Research, 5:1, forthcoming.

Goode, Luke and Michael Godhe (2017): "Beyond Capitalist Realism - Why We Need Critical Future Studies", Culture Unbound, 9:1, 108-129.

Habermas, Jürgen (1989[1962]): The Structural Transformation of the Public Sphere: An Inquiry into a Category of Bourgeois Society, Cambridge: Polity.

Hobsbawm, Eric (1975): The Age of Capital: 1848-1875, London: Weidenfeld \& Nicolson.

Hylland Eriksen, Thomas (2014): Globalization: The Key Concepts, Second Edition, New York: Bloomsbury Academic.

Levitas, Ruth (2013): Utopia as Method: The Imaginary Reconstitution of Society, London: Palgrave.

Manuel, Frank E. and Fritzie P. Manuel (1979): Utopian Thought in the Western World, Cambridge, MA: The Belknap Press of Harvard University Press.

Mason, Paul (2016): Postcapitalism: A Guide to Our Future, London: Penguin Books.

McKee, Alan (2016): FUN! What Entertainment Tells Us About Living a Good Life, London: Palgrave Macmillan.

Morris, William (1889): "Looking Backward", The Commonweal, June 22. Reprinted in William Morris (1993): News From Nowhere and Other Writings, Edited with an Introduction and Notes by Clive Wilmer, Harmondsworth: Penguin Books, 353358.

Morris, William (1890): New From Nowhere or an Epoch of Rest: Being Some Chapters From a Utopian Romance. Reprinted in William Morris (1993): News From Nowhere and Other Writings, Edited with an Introduction and Notes by Clive Wilmer, Harmondsworth: Penguin Books, 41-228.

Määttä, Jerry (2006): Raketsommar. Science fiction i Sverige 1950-1968. Lund: ellerströms.

Pak, Chris (2016): Terraforming: Ecopolitical Transformations and Environmentalism in Science Fiction, Liverpool: Liverpool University Press.

Paulsen, Roland (2017): Arbetssamhället. Hur arbetet överlevde teknologin, Stockholm: Atlas.

Robinson, Kim Stanley (1993-1996): The Mars Trilogy, New York: Bantam Books.

Schwab, Klaus (2016): The Fourth Industrial Revolution, New York: Crown Business.

Spencer, David A. (2009): "Work in Utopia: Pro-Work Sentiments in the Writings 


\section{Culture Unbound}

Journal of Current Cultural Research

of Four Critics of Classical Economics", The European Journal of the History of Economic Thought, 16:1, 97-122.

Stirling, John (2002): "William Morris and Work as it is and as it Might be", Capital \& Class, 26:1, 127-144.

Suvin, Darko (1979): Metamorphoses of Science Fiction. On the Poetics and History of a Literary Genre, New Haven \& London: Yale University Press.

Thomas, Theodore L. (1959): "The Good Work", If, February.

Vint, Sherryl (2016): "Introduction to "The Futures Industry", Paradoxa, Vol 27, 7-20.

Weeks, Kathi (2011): The Problem with Work: Feminism, Marxism, Antiwork Politics, and Postwork Imaginaries, Duke University Press: Durham \& London.

Zuzanek, Jiri (2017): "Work and Leisure in Thomas More's Utopia", Leisure Studies, $36: 3,305-314$ 